\title{
VOCATIONAL SCHOOLING AND ECONOMIC DEVELOPMENT: A MALTESE CASE STUUDY
}

\author{
RONALD G. SULTANA \\ Department of Educational Studies, Faculty of Education, University of Malta. Msida, Malta

\begin{abstract}
This article explores the promise, problems and pitfalls of vocational forms of secondary schooling when these are set up in developing, newly independent countries. Taking Malta as a case study, the author presents empirical evidence to examine some of the assumptions of human capital theory, and concludes that there are important limitations which stop 'trade schools' from responding adequately to the declared requirements for economic development. The reasons for the failure of such innovations need to be identified not only
\end{abstract} \\ from within the educational institution, but also from the wider, macro-economic context.
}

\section{INTRODUCTION}

Attempts to vocationalize Malta's educational systems $^{1}$ have a long history, and go back at least to 1798 , when, under the brief control of the islands by Napoleonic troops, the local University, born as a Collegium Melitense in 1592, was abolished and a technically-oriented Ecole Generale set up instead (Laferla, 1945). Since then, and throughout the British colonial period up to 1964 when Malta obtained its independence, various interest groups and, eventually, political parties presented technical education as one of the key solutions to Malta's main economie problem: the almost total absence of an indigenous industrial base. Various technical courses and schools were launched at different periods both by private and by state entrepreneurs from the 1850 s onwards, but most of these initiatives failed to attract and keep students long enough to give them adequate training, and indeed, what was provided was often 'too inappreciably connected with any great industry to be regarded as little more than an artistic branch of education' (Keenan, 1880).

The industrialisation of the nation failed to come about despite the very intensive investment in technical education in the post-war period. But, as has been argued elsewhere (Sultana, 1987, 1990, 1992), in a situation of dependence and fragility, only a few alternatives are available to a nation as it attempts to generate a self-sustainable economy, and the belief that education can be a solution to intractable economic problems is often maintained.
When the Malta Labour Party (MLP) came into government in 1971, a decision was made to vocationalize one third of the secondary level of schooling through the creation of 'trade schools'. The new schools were to have $75 \%$ of their curriculum dedicated to vocational skills training, and $25 \%$ to traditional academic lessons. This was justified, in the face of the opposition's criticisms that general education was being abandoned, by claiming that that was the only way a solid instruction in trades could be given. In her educational budget speech, Ms Barbara, the Minister for Education, insisted that trade schools would satisfy 'the demand for technical workers and tradesmen which the industrial expansion of our country is aiming for' (L'Orizzont, 29 May 1972).

While the official discourse on trade schools stressed their economic function, it is clear that these new institutions were to respond to other needs as well. Trade schools were to help change parents' traditional negative attitude towards technical education. They would respond to the special education needs of groups of students 'who either show a particular inclination for a trade, or for those who are not particularly keen to follow an academic education' (Times of Malta, 24 May 1972). Trade schools were to help check the serious unemployment problems which plagued Malta as it tried to restructure its economy and remove its independence for work on the British military base. Emergency labour corps had been established to mop up some of the unemployed, but another 'solution' was to raise the school-leaving age from 14 to 16. Reluctant school-attenders who found 
themselves blocked from entry into full-time work had to be offered a palatable alternative to the 'irrelevant' academic schooling then offered, and trade schools, which promised to reproduce the workshop environment besides continuing with general education, were thought to be attractive to those who were either unable or unwilling to pursue traditional courses of study.

The rise of these vocational institutions at the secondary school level, and their ability to respond to ideological, educational and political goals has been documented in detail in another context (Sultana, 1992). What this article sets out to do is to explore the extent to which these trade schools have in fact fulfilled the economic function which the MLP government established for them.

To do this, the article draws on a wide data bank collected within a 'Trade School Research Project' (TSRP) which the author directed between 1988 and 1992. Quantitative and qualitative research methods used included a detailed questionnaire with 680 fifteen year old trade school students, three tracer studies with 258 ex-students, ${ }^{2}$ in-depth interviews with 241 students, 137 teachers and instructors, and 60 industrialists, and more than 800 hours of classroom and staffroom observation in trade schools. ${ }^{3}$ The quantitative data are supplemented in some areas by surveys carried out by the Guidance and Counselling Unit of the Department of Education, the School Industry Unit and Gallup between 1987 and 1990. Other forms of documentary evidence were culled from newspapers, and files held at the Department of Education.

\section{HUMAN CAPITAL THEORY}

The setting up of trade schools represented the most fundamental effort on the part of the Labour Government to link education to the needs of the economy. That effort must not be divorced from other similar attempts by different governments and sustained through the nineteenth and twentieth century as the economy suffered the vagaries of time, or from attempts which were to be made at a later date and addressed at tertiary education. ${ }^{4}$

All these efforts, past and present, were based on a number of assumptions about the link between education and the economy, assumptions which were articulated in a theoretically sophisticated manner by a series of economists from the 1950s onwards through the formulation of what has come to be known as 'human capital theory'. This refers to a view of education as an industry which generates the desired amounts of functional manpower. Knowledge is considered by the likes of Peter Drucker, B. A. Weisbrod and T. W. Schultz, as the only real capital in modern times, and hence, the development of educated people - in vocational and general terms - is the most importarit capital formulation, and their number, quality and utilization the most meaningful index of the wealth-production capacity of a country (Sobel, 1978).

The implications of such views are clear. namely that 'education will produce an increase in general and in job-specific knowledge which individuals subsequently can apply in an expanding economy both to better utilize new technical developments and to generate innovations. Thē result will be a marked payoff in terms of increased production yielding greater national wealth, corporate profits, and individual wages' (Violas, 1981). Other related assumptions underlying human capital theory are that individuals choose to invest in education and are rewarded accordingly in the labour market, that skills, attitudes and competencies acquired in education are transferable to the workplace, and that the increasing complexity of the workplace and technology requires a higher level of skilling of all workers (Blackmore, 1990).

In Malta, it has been tempting for governments to assume that economic development cannot come about unless there is a highly and appropriately skilled work force, and that one of the ways of achieving that goal is to have diversified educational systems which provide technical education. That assumption has been constant and practically uncontested. For the post-war period in particular, and in synchrony with developments in other parts of the world, vocational schooling was considered to be a solution to the needs for the diversification of the economy. British consultants in the human capital tradition, such as Thomas Balogh and Paul Streeten, engaged critically with the American school of thought (Balogh and Streeten, 1968), but ultimately advised the Maltese (and other) governments to invest in technical education, 
and to embark on five or seven-year plans to calculate and provide the future manpower and skill requirements (Balogh, 1962a, b).

The work of Foster (1968) and of Blaug (1973), Berg (1970), Jencks (1972) and Collins (1979), and later of Psacharopoulos (1987), shattered the confidence in human capital that had hitherto been unchallenged. But as the latter scholar pointed out, 'because of its inherently logical and simplistic appeal, vocationalism will be with us for years to come, and more countries will attempt, in vain, to tune their formal educational systems to the world of work' (Psacharopoulos, 1987).

\section{QUESTIONING THE ASSUMPTIONS OF HUMAN CAPITAL THEORY}

The main assumptions implicit in human capital theory, and with particular reference to vocational schooling, can be presented in a schematic manner. Each of the following assumptions will then be dealt with individually, with each section drawing upon comparative educational literature and empirical studies related to the Maltese context, to evaluate the status of each claim. Briefly then, the economic assumptions on which vocational schools in Malta were developed state that:

1. Schools are well-placed to provide vocational education.

2. Schools can provide skills required by industry in the future.

3. Vocational students do the work they have been trained for.

4. There will be positive rates-of-return for vocational students.

\section{Schools of vocational education}

There are many problems associated with the assumption that schools are well-placed to provide vocational education. Vocational schools and tracks are generally much more expensive to run than general schools and tracks (Lauglo, 1987; Moura Castro, 1987), not only in terms of expenditure on material resources (Psacharopoulos, 1987), but also because class size has to be kept low for pedagogical and safety reasons (Munbodh, 1987). Given the general expenses involved, adequate allocation by the education budget to maintain vocational schools is often lacking, and this is especially true of many developing countries since most of these started off this form of schooling after receiving funding from international agencies. Once these sources dried up, they then found themselves unable to keep on providing new and up-to-date machinery, tools, equipment or the in-service up-dating courses for technical teachers (Tilak, 1988).

Educational institutions, hampered by bureaucratic forms of administration, have generally found it difficult to respond to new needs when these are signalled by the labour market (Bowman, 1988), and are often in an impossible situation having to 'prepare students for labor markets without having any control over labor markets themselves or knowledge how these markets will develop' (Grubb, 1985).

On the other hand, there is a lot of evidence to suggest that industry can train its workers more efficiently, faster and more cheaply than schools can. Industry is clearly more successful than schools can ever be in the creation of the direct experience of production. In addition to this, the training provided by industry is less costly because the workplace has machinery and personnel already used for production and hence incurs less overheads, while students need not forego earnings because they tend to be already employed, or involved in apprenticeship schemes, in the firm which provides the training. Students who are trained on the job and induced in that work environment are much more likely to choose - and remain in that job, and to be retrained by their employer who has already invested in them. Commitment by the student and the employer is likely to be higher, because both are paying for the training in their own ways, and both wish to re-coup the investment made (Psacharopoulos, 1988, 1987).

Employers in most parts of the world have in fact generally recognised that schools are not well equipped to provide vocational education, and expect schools to give a good basic education and social and attitudinal skills rather more than credentials, academic or vocational (Bowles, 1973; Oxenham, 1987). Given the complex and changing demands of the workplace, employers increasingly cite literacy, flexibility, good work habits, self-discipline, problem solving skills, and general knowledge as the key qualities they look for in prospective employees (Oakes, 1986; Semple, 1987).

Most of the extant literature therefore suggests rather strongly that Grubb's hypothesis that the historical ineffectiveness of vocational 
education can be at least partly explained by the fact that 'it has attempted to do what schools do worst' (Grubb, 1978).

The Maltese case study under consideration bears out this hypothesis. Malta's trade schools have been generally unable to respond to the needs of employers and of a changing labour market. A number of Federation of Industry position papers $(1988,1989,1991)$ have criticised the quantity and quality of technically trained tradespersons, and while noting that 'the country's educational system is not expected to provide personnel at all levels tailor made for a particular industry . . . it is certainly expected to provide personnel suitably trained in the basics that form the platform for the various industrial sectors' (FOI, 1989).

The Federation has insisted that one of the key obstacles to the development of the economy is the serious skills shortage in the light engineering sector, where Malta is looking to new, high-tech investment. Schools have been unable to respond to the needs for training in the new skills required (The Times, 9 March 1988; The Times, 30 October 1991). The Federation favours a dual training system of vocational education because in this way, private manufacturing companies can offer modern machinery, up-to-date instruction, and the best learning environment since industry offers, better than any school workshop can, the direct experience of production (Ellul, 1990).

A Skills and Training Needs Survey carried out in July 1987 by the Education and Industry Unit with 396 firms concludes that there is a widespread demand by employers of large, medium and small firms for more 'trainable' people (Harper, 1990). In other words, employers are looking for personal qualities such as motivation, adaptability, standards of work and sense of responsibility, as well as general education, that is literacy and numeracy, the ability to read and follow simple instructions, convey messages accurately, understand simple diagrams, perform basic calculations, and have knowledge of such matters as wages, social security, work books and trade unions. While the demand for technification implies the need for an increase of $30 \%$ at the trade school level, an emphasis was placed by several employers on the up-grading of the general level of education of unskilled labour rather than on specialised training, and basic rather than advanced technical knowledge was seen to be more useful because of changing machinery which is increasingly becoming much more highly technological (Harper, 1990). In-depth interviews with sixty employers also revealed that at the levels where trade school students are employed, it is character traits rather than educational or even skills qualifications that are given priority (Zahra and Ebejer, 1992).

Malta's employers generally expressed themselves dissatisfied with the nature of training offered in trade schools, wanting more up-todate instruction to be given by more adequately trained instructors, with students utilising more appropriate equipment. Some employers noted that trade school curricula were restricted, dealing mainly with basic processes, tools and machinery, and many suggestions were made urging the introduction of various skills-training courses reflecting new directions in production. A report commissioned by one trade school and prepared by a consultant from the Centro Analisi Sociale -of Turin noted that 'machinery and other training equipment available are obsolete and, in some cases, not even operational in view of the lack of parts and maintenance' (1991). Funds to redress this situation are becoming less and less available as financial priority is increasingly being given in the Maltese educational budget to the postsecondary educational level.

While, according to the Skills and Training Needs Survey, some firms were ready to provide machinery and instructors to trade schools, most were unwilling to incur the costs of training, even when, in the long term, they were the direct beneficiaries and recouped the investment made in human resource development. A UNIDO report on technical training in Malta confirms the tendency for industry to rely on the vocational training provided by schools, even when they claim to be unhappy with the result (Harper, 1990). The report argues that employers must be induced to play their part in industrial training programmes, with personnel being released to train teachers and students, and equipment being made available for use in their firms. They could also help by providing up-dating courses to teaching staff in trade schools and technical institutes.

The criticisms which employers have levelled at trade schools must not be accepted at face value. Some of the issues that have been raised show a lack of understanding of the role of vocational schools at the secondary level on 
the part of industrialists. Trade school curricula aim to provide local firms with workers at the operative and basic crafts level, and not with technicians. ${ }^{5}$ In addition to this, the Maltese industrial set-up is characterised by a large percentage of small firms employing less than twenty workers. ${ }^{6}$ Such firms are not likely to offer the training facilities that the Unido report recommends. Most firms are also unlikely to require an advanced degree of technical skills.

The insistence since 1987 by a centrist government that Malta will be transforming its market orientation towards high technological fields, that more sophisticated skills will therefore be required, and that vocational schools should change curricula to aim for such sunrise industries, is problematic. Various studies have suggested rather strongly that the widespread and long-standing belief that an increasingly technological society requires a skilled populace is questionable (Braverman, 1974; Littler, 1982). Rather, what has been shown is that the increasing technocratisation of society has resulted in increased skill requirements for some and a decrease in skill for others (Hill, 1981; Gordon et al., 1982). Increased application of technology has in many cases reduced complex mental or physical skills to routine task requirements capable of being performed by most individuals without extensive technical training. This seems to be as true in the so-called white-collar professions as it is in more typically blue-collar occupations (Johnson, 1982). Where technology has increased the skill requirements for jobs, this has mainly been true for a small group, namely those who plan the techniques of production.

Additionally, while some 'high-tech' jobs, such as those of systems analysts, computer programmers, data-processing machine mechanics, and others, are projected to grow between $74 \%$ and $148 \%$ in the nineties, their absolute number is small, while increases in unskilled categories as janitors, nurse-aids, fast-food workers and so on will grow at unprecedented rates. Various economists have in fact concluded that more and more workers will be required by the nature of the economy to take jobs which do not make use of their education and skills, and that formal education certification will be more useful in getting rather than in doing a job (Levin and Rumberger, 1983).

There is some evidence that the same trend obtains locally. The Skills and Training Needs Survey notes, for instance, that several companies were losing good and qualified workers because the present occupations under-utilised their skills and levels of training. Furthermore, some specialised companies in nonferrous metals employ those with limited experience and poor levels of education so that these employees 'would not be able to understand pertinent technological details that would enable them to set up on their own and become a competitive threat' (Harper, 1990). The Trade School Tracer Studies show that up to $61 \%$ of early leavers and $47 \%$ of course completers were doing the same work as colleagues who had not been to the vocational schools but followed the general stream instead. Indeed, it could be argued that the present skills shortage is a socially constructed problem, given that skilled labour is poorly paid and hence will not attract workers, and that there is still occupational segregation in Malta, which automatically excludes women from vacancies which employers claim they cannot fill (Darmanin, 1992).

These caveats serve as an important reminder that employers generally have vested interests when they make claims or register complaints about the educational system. Nevertheless, industry's dissatisfaction with trade schools does alert us to the fact that schools are notoriously inadequate institutions for vocational training to take place in. The most obvious case which demonstrates the extent to which schools find it difficult to respond to changes in the labour market is the vocational training offered in Maltese girls' trade schools. Girls are channelled to work in textile firms. Other skills provided consist of craft-type activities which prepare students for domestic work or the tourist industry. While the focus on industrial sewing might have been functional in the early seventies, when the textile industry was 'the dominant and most important sector of Maltese manufacturing establishments and the largest provider of jobs in the private sector' (Micallef, 1992), the labour market situation has now changed, without a concomitant reform in trade schools.

Indeed, due to the availability of cheaper labour in the Maghreb and in Central and Eastern European countries, general world recession, and changes in government economic policies and in the regulation of exports, the textile industry in Malta is shrinking drastically, 
with twenty nine factories closing down over the past five years, with others trimming their work force. In all, 2250 workers have been shed between mid-September 1987 and endSeptember 1991 (Micallef, 1992). But trade schools continue preparing girls not only for some of the lowest paid, semi-skilled occupations available, but for jobs which might no longer be there.

\section{Schools and industrial skills for the future}

A second claim of human capital theory is that one can tell which industrial skills will be needed in the future, and that vocational education programmes can therefore engage in the preparation of future manpower needs. Such manpower planning has had an appeal for many governments in the post-war era as they tried to project the types and number of skills needed by the economy in the future so that the educational system would then produce the right number of persons with the appropriate skills. Malta is no exception, and under the influence of Balogh in the 1950s, successive administrations embarked on a number of manpower planning and forecasting exercises, the latest version being one announced recently by the Employment and Training Corporation ${ }^{7}$ with the intention of conducting a comprehensive survey on a national basis to identify labour and skills requirement in order to give the government as clear a picture as possible of present and future needs, enabling it to draw up its education and training policies' (The Times, 2 May 1992).

Despite the rhetoric accompanying the launching of an exercise which would place Malta 'in the forefront of future discussion' on the subject in international fora such as the ILO, 8 the evidence from a number of countries over the past quarter century has generally discredited attempts at manpower planning and forecasting. Among the reasons that are usually given for the difficulties facing such an exercise are the following (Bulletin of the International Bureau of Education, 1986): the greater frequency and speed of change in the technology/employment area than in the education/training area; the assumption that persons trained in a given occupation will seek that employment; the unreasonable assumption of zero labour substitution; the narrow focus on wage employment in the formal sector to the exclusion of all other forms of economic activity; the focus on growth to the exclusion of equity and social demand; the discrepancies between the actual rates of economic growth and the assumed ones upon which the manpower forecasts are based; the neglect of occupational mobility; and the assumption that particular levels of economic development are reached through specific patterns of educational/occupational structures.

To these we can add Malta's vulnerability to changes in the international market which play havoc with plans of vocational training initiated in response to projected personpower needs. The mobility of capital makes investment by multinational companies highly unreliable and small states find it particularly difficult to plan ahead (Munbodh, 1987; Baldacchino, 1992). In addition to this, Malta's recent decision to liberalize its economy has further repercussions on manpower forecasting, given the fact that the only places where the latter has tended to be successful is in centrally planned economies. Here, 'state bureaucracies establish investment policy, set production schedūles, organize the distribution of the labor force and determine the content and enrollment level of educational frameworks. Given their strong commitment and actual power to control economic production, it is not surprising that the educational systems of Eastern Europe have been organized to keep in step with, and to be an instrument of, economic development' (Benavot, 1983). In other countries, these attempts have failed (Youdi and Hinchcliffe, 1985), often miserably, and have in fact generated unemployment because 'the skills assessed as of today that would be needed twenty years from now, will be very different from those that the economy will be actually demanding in the future' (Psacharopoulos, 1991).

\section{Vocational education and career paths}

Most research carried out in developing and developed countries shows that the assumption that students will find, or even look for work in the area related to their training is unfounded. Lewis and Lewis (1985) review research reporting trends in the Caribbean, for instance, and tracer studies carried out in a number of islands in the late seventies and early eighties confirm general findings elsewhere that large percentages - between 25 and $33 \%$ - of vocational students were not working in the course-related jobs. Similar results have been 
obtained from tracer studies with students following vocational tracks in American high schools. In this case, only $27.4 \%$ of the employed graduates had a training-related job 1 to 10 years after leaving high school (Bishop, 1986). Another study showed that only $21 \%$ of employed vocational graduates had a trainingrelated job two years after finishing high school (Campbell et al., 1986). The countries which have reported higher percentages of graduates in training-related jobs have been those which like Germany, have employers who are heavily involved in the training offered to students.

A number of studies carried out in Malta evince many of the problems outlined above with reference to both job orientation and job placement. The 1989 data from the Trade School Research Project Questionnaire (TSRPQ) suggests that in intention at least, $59.7 \%$ of male students and $53.6 \%$ of female students think their main job will be in the trade area they have studied at school. Only $9.3 \%$ of male students said they would be working in an unrelated area. The percentage for females in this case was significantly higher, with $24.2 \%$ saying they would be working in a different field altogether. It is also significant to point out that $20.1 \%$ of the female and $29.4 \%$ of the male students did not answer this question, suggesting a degree of uncertainty about their occupational futures, and that young adults entering the skilled and semi-skilled labour market segments are more prone to take up what is available than to choose jobs. In other words, there are jobs looking for people, rather than people looking for jobs (Roberts, 1977). ${ }^{9}$ This readiness to enter the labour market when openings presented themselves can be partly understood when $45.4 \%$ of the female, and $45.5 \%$ of the male students said they were not quite sure whether it would be easy or difficult to find employment on leaving school, while $21.1 \%$ of the girls and $10.9 \%$ of the boys declared it would be difficult to find a job.

The best way to find out which occupations vocational students have in fact taken up is through tracer studies. One such study was carried out by the Guidance and Counselling Services (1990) of the Department of Education in October and November 1990 with all June 1990 school-leavers. This shows that of the 561 male vocational graduates who replied, representing $82.5 \%$ of the total who received the questionnaire, $20.9 \%$ were in manufacturing work. $7.3 \%$ reported that they were working in the tourist industry, while another $13.2 \%$ said they were working in the service sector. The last two figures show that $20.5 \%$ of all vocational school-leavers were in an occupation which trade schools had not prepared them for. In addition to this, one cannot assume that those in manufacturing work were doing training-related tasks. This is borne out not only by other tracer studies reported below, but also by data obtained from interviews with trade school heads who noted that students applied to fill dockyard vacancies, for instance, irrespective of the trade they were taking at school.

Data for girls are less convincing because the response rate of $45 \%$ (i.e. 205 of 457 schoolleavers) is relatively low. In this case, $72.1 \%$ of those who replied were in manufacturing work, and, given employment opportunities for women in Malta, were almost certainly in textile factories. $4.8 \%$ were in tourism, $2.9 \%$ in services, while a full $15.1 \%$ remained 'at home'. In any case, $89 \%$ of the girls said they would not remain in full-time employment once they had children.

Two other tracer studies were carried out by members of the TSRP team on a questionnaire designed by the present author. These tracer studies (henceforth referred to as TSTS) set out to contact two groups of male students, early school-leavers and course completers, who entered employment in 1987/88. In the case of early school-leavers, $71.6 \%$ were working in jobs totally unrelated to the trade they had studied at school. The course-completers were more likely to have benefited from their trade training, since 'only' $38.7 \%$ had found employment in course-unrelated occupations. ${ }^{10}$ This could mean that students take some time until they actually find a job related to their training.

\section{Rates-of-return for vocational students}

If a key dimension in the evaluation of educational programs is the benefits they provide to their clients - students - then it becomes important to explore at some length whether vocational schooling gives students any advantages in the labour market when compared to 'non-vocational' students. In other words, it is not sufficient to evaluate the rates-of-return of trade schooling for the nation, but also for its graduates. Most studies which have attempted 
to address this issue have attempted to answer one or more of the following questions:

- Do vocational students find employment quickly?

- Are they more likely to be unemployed?

- How do their wages compare with those received by non-vocational students?

- What conditions of work do they enjoy?

The evidence reported by a number of countries is mixed and therefore inconclusive. Some claim that students trained in a vocation do better in getting jobs than students opting for a general education (Freedland and Little, 1980). A study carried out with 12,000 young people by the U.S. National Center for Research and Vocational Education, for instance, found that the more vocational courses the student takes, the more likely s/he is to find a job (Campbell, 1981). Depending on the condition and performance of the labour market, Norwegian vocational students do in fact do better in terms of earning, feeling of autonomy on the job, participation in trade unions, and other such measures. These advantages are especially significant when we consider that vocational track students have often stayed for a shorter period in schools (Lindbekk, 1989). However, a review of income returns to graduates from academic and vocational secondary education in several Asian and African countries suggests that for many countries, there are short-term returns for vocational education graduates, but in the long-term, the pattern changed to the benefit of those from academic lines. In France, graduates in the general education schools come off better in the short-term as well (McMahon, 1988).

Research has also indicated that for those who do not pursue their studies at college/postsecondary level, the high school curriculum had little effect on labour market outcomes, irrespective of whether that curriculum was general or vocational (Myer and Wise, 1983). A major study by the Bureau of Labor Statistics concluded that of the 53 million Americans employed in jobs which required training, only $5 \%$ received it in high school vocational classes. The same study also indicates that business/office studies, often followed by female students, represent one of the few vocational areas that do give an advantage in the labour market (Carey and Eck, 1984). Psacharopoulos (1987) concludes that there is really no hard evidence that returns for individuals, or for society generally, are any better with vocational streams, even when one looks at their effect in developing countries. Indeed, vocational education students are more likely to spend longer periods unemployed. Tilak (1987) arrives at much the same conclusions after reviewing fourteen studies carried out in developing countries.

Given the nature of the conflicting evidence available, some have argued that it would be safe to conclude that training in certain occupational areas gives more benefits to students than others (Mertens, 1983), and that vocational education can make a small positive difference for some of the people some of the time (Claus, 1990).

There are a number of problems which must be highlighted before the Maltese empirical data are compared with that obtaining from international studies. A key issue which is not often raised is that an important variable in the rates of return for students might not be whether s/he followed a vocational or general track, but the nature of the reward structure of the labour market which absorbs school-leavers (Lewis and Lewis, 1985). A second problem is that when comparison is made between the rates of return for vocational and for general students, it is often forgotten that these two types of tracks attract different 'types' of students, with the vocational catering for what are often socio-economically depressed groups of students. Even if these achieve less, in financial terms, than general education students, one would have to see whether their rates of return would have been as good or bad had they too joined the general stream (Moura Castro, 1987).

A related issue is that vocational students are a 'self-selected group' likely to possess not only similar backgrounds, but also skills and aspirations which are different from those of the groups with which they are compared. Thus, 'differences which appear between vocational and nonvocational groups at the completion of a program may reflect not program impact, but prior differences which escaped detection of the survey measures. Alternatively, such differences may reflect differential interactions between certain kinds of students and certain program features' (Claus, 1990). 
Furthermore, differences between the results obtained by male and female students reflect the different opportunities and rewards that a segmented labour market presents to the different genders.

In addition, most of rates-of-return studies do not explain why vocational education graduates tend to do less well. The reason for this may be in the different value that specific as against general skills have for employers. The former are those that are useful to one employer, while the latter are those which every employer finds productive. The employer need not pay narrowly skilled workers higher wages than those prevailing for unskilled labourers, since the specific skills are useless to any other firm and there is no incentive for other employers to bid specifically skilled workers away. In the case of general skills, however, employers will try to poach workers by offering them higher wages. Thus, while it behoves employers to train specific skills, the general skilled persons are more productive to all firms, and their wages must be increased in order to hire them. With specific skills, the benefits of that training may be captured by firms instead of workers (Grubb, 1978).

The Trade School Tracer Studies carried out in Malta indicate that vocational students do not generally encounter many difficulties in finding a niche in the local labour market, though obviously one needs to examine the status of that niche, preferably in comparison with the sorts of opportunities available to students who graduate from other schools. Over $80 \%$ of early leavers and $94.6 \%$ of course completers who responded to the TSTS questionnaires were in employment, with most - $60 \%$ of the former and $88 \%$ of the latter - finding a job within six months of leaving school. With a situation of almost full employment, this is not surprising and the relative advantage or disadvantage of vocational school students is not clear. However, an analysis of the 16-18 year old young adults registering for unemployment showed that the most at risk were, first, those who had only primary schooling, and then those who had attended trade schools. $30.9 \% \quad(n=157)$ were male students who had completed the trade school course, while $28.7 \%(n=146)$ had left vocational schools early. Females were not highly represented in the list of registered unemployed (Mallia and Borg, 1993).
In addition to this, the TSTS show that most vocational school students found themselves in unskilled $(45 \%$ of early leavers; $9.9 \%$ of course completers) and semi-skilled work ( $41.3 \%$ and $42.3 \%$ respectively). The Skills and Training Needs Survey confirms this pattern, noting that $12 \%$ of the workers from a technical education level were found to be employed in unskilled occupations, and considers this to be a 'disturbing result' which called for further investigation (Harper, 1990). Almost $70 \%$ of early leavers and $47 \%$ of course completers felt that somebody who had never attended a trade school could have performed the same type of work they were presently doing.

The computation of the financial rates-ofreturn for vocational track students compared with general track students is complex in itself because, as noted earlier, there are a number of variables involved, so that any final conclusions might be referring to elements other than program effects. A major factor to be considered is the reward structure in Malta, where sixteen years of Labour administration reduced wage differentials between manual and non-manual labour as well as between different working grades (Zammit, 1984). As Carnoy (1990) has pointed out with reference to societies which embarked on a socialist program, 'The individual material cost of not doing well in school is greatly reduced, and so is the material payoff of reaching higher levels of schooling. The motivation for high achievement in school comes in part from the continued (but smaller) differences in income, but more from nonmaterial rewards (such as easier, more prestigious jobs and political power) and from pressures of social responsibility (a more productive life and a greater contribution to the people-nation)'.

The particularity of the reward structure of the Maltese labour market is perceived by students, and is reflected in their beliefs about the effectiveness of schooling in increasing earning power. These perceptions were once more influenced by the gender of respondents. Data from the TSRPQ show that $27.8 \%$ of boys in Trade Schools said they were sure that vocational schooling led to jobs which were as well paid as jobs which required academic schooling. A further $37.1 \%$ said they were not sure about what was most remunerative, while $30.7 \%$ said that academic schooling gave better rates of return. Girls seemed to 
think that vocational schooling was generally less remunerative, with $46.4 \%$ expecting their counterparts in general schools to earn more money than themselves. $37.1 \%$ were not quite sure, while only $8.3 \%$ thought that vocational schooling put them ahead, in terms of earning power, than others.

While trade school students were generally uncertain as to whether vocational schooling gave them more earning power than general schooling, the TSRPQ data show that they expected their training to contribute to higher earnings in the future, when this was compared to the earnings of untrained workers in similar work environments. This was true of $82.1 \%$ of male students and $72.7 \%$ of females. Indeed $51 \%$ of the former, but only $15.5 \%$ of the latter thought it would pay to invest in further vocational education. ${ }^{11}$ The tracer studies suggests that this faith in schooling decreases, but is still significantly high when male trade school graduates look back from the vantage point of employment to comment on whether further study in a trade would have given them better job possibilities. Thus, the TSTS with early leavers shows that $65 \%$ thought that had they stayed longer in a vocational school, they would have had better job possibilities, while $47.8 \%$ of the course completers were of the same opinion. However, a significantly high percentage from both groups, $32.8 \%$ and $38.7 \%$ respectively, felt that further study would not have made much of a difference in job opportunities and rewards.

If one compares the above expectations with actual wages earned by $1987 / 88$ vocational school graduates represented in the TSTS, it then becomes clear that a full $45 \%$ of early school leavers were not succeeding in earning the minimum wage (Bianchi, 1992; Vella, 1992). ${ }^{12}$ As to course completers (Chetcuti, 1992), 13 these were earning, in general, slightly above the minimum wage. It is significant that $44.1 \%$ of early school leavers and $43.2 \%$ of course completers remarked that low pay was a major drawback at their place of work.

This does not represent the whole picture, however. If one is to put a value on the vocational training that trade school students receive, one has to keep in mind the phenomenon of Malta's underground economy, which accounts for between 10 and $20 \%$ of the GNP (Delia, 1987). From the TSRPQ data and interviews with trade school students it became clear that the latter were very likely utilising their vocational skills in a second, unofficial job. Thus, $37 \%$ of the male and $7.2 \%$ of the female students who answered the TSRPQ expressed their intention to have a second job. ${ }^{14}$ By far the greater majority of male trade school students aspired to work with governmental or parastatal bodies.

The Skills and Training Needs Survey reported similar data, with $41 \%$ making the Government sector their first choice (Harper, 1990). The TSTS show that, by and large, these intentions seem to be followed when students enter the labour market, with, on average, $25 \%$ being employed by the state and $45 \%$ by private industry. While a very small number, six students in all, had in fact set up on their own, it is likely that many of them were earning over and above their wage by doing other jobs. The Skills and Training Needs Survey notes that many trade school students aspired for government jobs because of the job security that sector offered, and also because it left them enough time to work part-time elsewhere. Informal, unstructured interviews with male trade school students revealed that some preferred to first work with the government until they had learned their trade well, and once they had obtained experience and expertise, they intended to leave state employment and start their own enterprise, perhaps by turning a secondary job into a primary one. No information is available as to whether these secondary jobs correspond to skills learnt at school. If this were found out to be so, then vocational schooling might be contributing not to development in the formal but the underground economy.

\section{CONCLUSION}

This article has shown that the economic goal established for trade schools has not, in fact, been reached, since these schools are not responding - and cannot respond adequately enough to the economic needs of the nation, and are most probably not bringing enough returns to the students who follow courses there. Large numbers of vocational students take up main jobs unrelated to their training while most female trade school students are more likely to quit their job as soon as they have had children. As a result, the nation cannot recoup investment made in 
its attempts to develop a skilled workforce. All these reasons militate against vocational schools performing the direct economic function that was intended for them. The most that one can claim is that these schools fulfil an indirect economic function

(a) By building up a technological culture in the labour force (though it seems that high rates of absenteeism, as well as outdated technology in schools, jeopardize this function), and

(b) By directing a percentage of students away from academic education and into blue collar occupational paths.

The second goal could never be a declared intention for schools in a nation which overtly claims that justice and democracy are its guiding values.

Trade schooling does not seem to bring much in the way of advantages to students who are channelled, or choose to go to that particular educational structure. Vocational students are more likely to be unemployed than students from other types of schools, and generally find work as unskilled and semi-skilled workers, so that they are ultimately engaged in doing work which others who have not gone to trade schools can do. In addition, they are exposed to a restricted general carriculum which should be considered a disadvantage, not only from the civic but also from the industrial point of view.

Finally, an evaluation of the returns of vocational schooling for the nation and for the individual student must be placed within a macro socio-economic context. Whether this kind of schooling will bring more or less advantages or disadvantages will depend on such factors as the rate of growth of the overall economy, and particularly of the sector which will make use of the vocational skills taught; the structure of incentives and disincentives that influence the allocation of available specialised labour; the quality and relevance of the education that vocational students bring with them to the labour market, and so on. Government policies, such as in increasing or decreasing wage differentials between blue and white-collar work, will also have a direct impact on the attractiveness of, and/or rates-of-return for, vocational schooling. In other words, the reasons for the economic success or failure of trade schools need to be identified not only from within the educational institution, but also from the outside. Other variables, that have nothing to do with education as such, must be examined.

\section{NOTES}

1. Malta is made up of a group of small islands. two of which are inhabited. The larger island, Malta, has. a population of around 325,000 , while Gozo's population is around 25,000. The archipelago of islands covers a surface area of about 316 square kilometres. It occupies a strategic position in the Mediterranean Sea, lying 93 kilometres to the south of Sicily and 290 kilometres to the north of the African Coast. Malta's position in the middle of the Mediterranean Sea and its natural harbours have invited a number of colonial powers - the Carthaginians, the Romans, the Byzantines, the Arabs, the Normans. the various houses of Spain, the French, and finally the British - to take possession of the islands. Malta obtained its political independence from Great Britain on 21 September 1964, and was declared a Republic on 13 December 1974.

2. Three tracer studies were carried out with two groups of students. The first group consisted of students who left their trade school before the completion of their third year in 1987/88 (Vella, 1992; Bianchi, 1992); the second group was made up of those who had left after the completion of their third year in 1987/88 (Chetcuti, 1992). The intention is to follow the students sampled through their occupational careers for a number of years to come, in order to facilitate an extended study of the same respondents. This longitudinal dimension will generate important data regarding the effects of vocational schooling over a period of time.

3. The research team was made up of graduate and undergraduate students following courses in the sociology of educational development at the University of Malta. Their contribution to the overall research project is acknowledged in various places throughout this paper, where reference is made to dissertations submitted in partial fulfilment of degrees and diplomas. All research tools were designed by the present author, and the qualitative dimension of the study is based on the grounded theory approach pioneered by Glaser and Strauss (1967).

4. The technification of tertiary education was attempted four years after the introduction of trade schools (Tertiary Education: Proposed Reforms, Department of Information, Government Printing Press, Malta, June 1978).

5. cf. Report of the Round Table Conference held at Umberto Calosso Trade School, St. Venera, between Industrialists and Educators, May 31989 (mimeo), pp. 2-3. Also, most of the trade schools teaching staff interviewed made the same comments.

6. In 1987, $88.5 \%$ of workers in manufacturing, quarrying and construction and non-manufacturing industries were to be found in establishments employing 
less than twenty people (Central Office of Statistics, Abstract of Annual Statistics, Malta 1988).

7. A Maltese version of the British Manpower Services Commission.

8. The Minister of Education and Human Resources, Times of Malta, 2 May 1992.

9. Data similar to that reported in the TSRPQ can be found in a Gallup study which found that $27 \%$ of trade school students were as yet uncertain about their future careers. GALLUP 'Trade/Technical School children: Attitudes Towards Work Motivation and Perception of Industry: Summary Report', 1990, p. 17.

10. The data do not reflect the frequent occupational shifting these young workers were involved in since their graduation, or the changes they intended to make in the future.

11. One has to keep in mind that these results represent a biased sample, i.e. those who answered were those present in trade schools, and therefore represent those who had made a decision that it was better to attend school than not to.

12. This percentage is worked out of the total of those who answered the relevant question, i.e. 42 (or $60 \%$ of Vella's sample) and 71 (or all of Bianchi's sample).

13. 78 out of 111 , or $70.2 \%$ of Chetcuti's sample answered the relevant question.

14. This is a conservative number, given the fact that many students might have felt threatened by the question.

\section{REFERENCES}

Baldacchino. G. (1993) Bursting the bubble: the pseudodevelopment strategies of microstates. Development and Change 24, 29-51.

Balogh, T. (1962) Catastrophe in Africa. Times Educational Supplement. 5 January 1962.

Balogh. T. and Seers. D. (1955) The Economic Problems of Malta: An Interim Report. Government Printing Office, Malta.

Balogh, T. and Streeten, P. P. (1968) The planning of education in poor countries. In Economics of Education (edited by Blaug, M.), Vol. 1. Penguin, Harmondsworth.

Benavot, A. (1983) The rise and decline of vocational schooling, Sociology of Education 56, 63-76.

Berg, I. (1970) Education and Jobs: The Great Training Robbery. Praeger, New York.

Bianchi, A. (1992) Trade School Tracer Study: Early Leavers. Diploma in Educational Administration and Management dissertation, University of Malta.

Bishop, J. (1986) Occupationally specific training in High Schools. In Re-Visioning Vocational Education in the Secondary School (edited by Copa, G. H., Plihal, J. \& Johnson. M. A.). Minnesota Research and Development Centre for Vocational Education. Minnesota.

Blackmore, J. (1990) The test and context of vocationalism. Journal of Curriculum Studies 22(2), 177-184.
Blaug, M.(1973) Education and the Employment Problem in Developing Countries. ILO, Geneva.

Bowles, S. (1973) Understanding unequal economic opportunity. American Economic Review 63, 14-23.

Bowman, J. (1988) Links between general and vocational education: does the one enhance the other? International Review of Education 34(2), 149-171.

Braverman, H. (1974) Labour and Monopoly Capital. Monthly Review Press, New York.

Bulletin of the International Bureau of Education (1986) Special Issue on education and employment, No. 238/9, Unesco, Paris.

Campbell, P. (1981) Employment Experiences of Students with Varying Participation in Vocational Education. National Center for Research in Vocational Education, Ohio State University, Columbus.

Campbell, P. B., Bassinger, K. S., Dauner, M. B. and Parkes, M. A. (1986) Outcomes of Vocational Education for Women, Minorities, the Handicapped and the Poor. The National Center for Research in Vocational Education, Ohio State University, Columbus.

Carey, M. and Eck. A. (1984) How workers get their training. Occupational Outlook Quarterly 28(4), 22-28.

Carnoy, M. (1990) Education and the Transition State. In Education and Social Transinion in the Third World (edited by Carnoy, M. and Samoff, J.). Princeton University Press, Princeton.

Central Office of Statistics (1988) Annual Abstract of Statistics. Government Press. Malta.

Centro Analisi Sociale (1991) Umberto Calosso Trade School: Technical Analysis/Survey (mimeo).

Chetcuti, H. (1992) Trade School Tracer Study: Course Completers. Diploma in Guidance and Counselling dissertation, University of Malta.

Claus, J. (1990) Opportunity or Inequality in Vocational Education? A Qualitative Investigation. Curriculum Inquiry 20(1), 7-39.

Collins, R. (1979) The Credential Society. Academic Press, New York.

Darmanin, M. (1992) The Labour Market of Schooling: Maltese Girls in Education and Economic Planning. Gender and Education 4(1), 105-106.

Delia. E. P. (1987) The Task Ahead: A Study on the State of the Maltese Economy. Confederation of Private Enterprise, Malta.

Department of Information (1978) Tertiary Education: Proposed Reforms. Government Printing Press, Malta.

Foster, P. J. (1968) The Vocational school fallacy in development planning. In Economics of Education (edited by Blaug, M.), Vol. 1. Penguin, Harmondsworth.

Freedland, J. E. and Little. R. D. (1980) Long-term returns to vocational training. Journal of Human Resources 85, 19-27.

Gallup (1990) Trade/Technical School Children: Attitudes Towards Work Motivation and Perception of Industry: Summary Report. Malta.

Glaser, B. G. and Strauss, A. L. (1967) The Discovery of Grounded Theory: Strategies for Qualitative Research. Aldine, Chicago.

Gordon, D., Edwards, R. and Reich, M. (1982) Segmented Work, Divided Workers: Historical Transformation of Labour in the United States. Cambridge University Press, Cambridge.

Grubb, Norton W. (1978) The phoenix of vocationalism: 
hope deferred is hope denied. New Directions for Education and Work, Spring, 71-89.

Grubb, Norton W. (1985) The convergence of educational systems and the role of vocationalism. Comparative Education Review 29, 526-548.

Guidance and Counselling Services (1990) Results of a Tracer Study held in October/November 1990, Education Department, Malta, mimeo.

Harper. J. D. (1990) Review of Skills Surveys To-Date, Malta, mimeo.

Hill. S. (1981) Competition and Control at Work. Heinemann, London.

Jencks. C. (1972) Inequality: A Reassessment. Basic, New York.

Johnson, D. (ed.) (1982) Class and Social Development: A New Theory of the Middle Class. Sage, Beverly Hills.

Keenan, P. J. (1880) Report on the educational system of Malta. Parliamentary Papers xlix, (C.2685).

Laferla, A. V. (1945) British Malta, Vol. 1. Aquilina \& Co.. Malta.

Lauglo, J. (1987) Practical subjects in Kenyan academic secondary schools. In: Vocationalizing Education (edited by Lauglo, J. and Lillis, K.). Pergamon Press. Oxford.

Levin, H. M. and Rumberger. R. W. (1983) The Educational Implications of High Technology. Institute for Research on Educational Finance and Government, Stanford, Ca.

Lewis, T. and Lewis, M. V. (1985) Vocational education in the commonwealth Caribbean and the United States. Comparative Education 21(2), 157-171.

Lindbekk. T. (1989) Education for life: vocational education and social integration in Norway. Comparative Education 25(1), 19-28.

McMahon, W. W. (1988) The economics of vocational and technical education: do the benefits outweigh the costs? International Review of Education 34, 38-54.

Mertens. D. (1983) The vocational graduate in the labor market. Phi Delta Kappan 64(5), 360-362.

Micallef, K. (1992) The rise and fall of the textile industry, The Sunday Times, 3 May 1992.

Moura Castro, C. de (1987) Is vocational education really that bad? International Labour Review 126(5), 603-610.

Munbodh, S. (1987) The technical education needs of the small states of the commonwealth. In: The Challenge of Scale (edited by Bacchus, K. and Brock, C.). Commonwealth Secretariat, London.

Myer, R. H. and Wise, D. A. (1983) High school preparation and early labor market experience. In: Youth Joblessness and Unemployment (edited by Freeman, R. B. and Medoff, J. L.). University of Chicago Press, Chicago.
Oakes, J. (1986) Beyond tinkering: reconstructing vocational education. In: Copa G. H. et al., op. cit.

Oxenham. J. (1987) What do employers want from education? In: Lauglo, J: \& Lillis, K., op. cit.

Psacharopoulos, G. (1987) To vocationalize or not to vocationalize: that is the curriculum question. International Review of Education 33(2), 187-211.

Psacharopoulos, G. (1988) Editorial introduction. International Review of Education 34(2), 143-148.

Psacharopoulos, G. (1991) Education and work: The perennial mismatch and ways to solve it. The Vocational Aspect of Education 114, 18-27.

Psacharopoulos, G. and Loxley, W. (1985) Diversified Secondary Education and Development. John Hopkins, Baltimore, U.S.A.

Roberts, K. (1977) The social conditions, consequences and limitations of careers guidance. British Journal of Guidance and Counselling 5(1), 1-9.

Semple, N. M. (1987) Vocational education: The missing link. Peabody Journal of Education 26(2), 70-90.

Sobel, I. (1978) The human capital revolution in economic development: its current history and status. Comparative Education Review 22, 27-34.

Sultana, R. G. (1990) Schooling for work in New Zealand. British Journal of Education and Work 3(3), 35-48.

Sultana, R. G. (1991) Social class and educational achievement in Malta. In: Themes in Education: $A$ Maltese Reader (edited by Sultana, R. G.). Mireva, Msida, Malta.

Sultana, R. G. (1992) Education and National Development: Historical and Critical Perspectives on Vocational Schooling in Malta. Mireva, Msida, Malta.

Tilak, J. B. G. (1988) Economics of vocationalization: $A$ review of evidence. Canadian and International Education 17, 45-62.

Tilak, J. B. G. (1988) Vocational education in South Asia: problems and prospects. International Review of Education 34(2), 244-257.

Vella, F. (1992) Trade School Tracer Study: Early Leavers. Diploma in Guidance and Counselling dissertation, University of Malta.

Violas, P. C. (1981) Reflections on theories of human capital, skills training and vocational education. Educational Theory 31(2), 137-151.

Youdi, R. B. and Hinchcliffe, K. (1985) Forecasting Skilled Manpower Needs: The Experience of Eleven Countries. Unesco, IIEP, Paris.

Zahra. S. and Ebejer, E. (1992) The wants and needs of industry: An educational perspective. B.Ed. (Hons.) dissertation. University of Malta.

Zammit, E. L. (1984) A Colonial Inheritance: Maltese Perceptions of Work, Power and Class Structure with reference to the Labour Movement. University of Malta Press, Malta. 